\title{
An Azidoribose Probe to Track Ketoamine Adducts in Histone Ribose Glycation
}

\author{
Igor Maksimovic $^{1,2}$, Qingfei Zheng ${ }^{2}$, Marissa N. Trujillo ${ }^{3}$, James J. Galligan ${ }^{3}$, and Yael \\ David $^{1,2,4,5^{*}}$
}

1. Tri-Institutional PhD Program in Chemical Biology, New York, NY, United States

2. Chemical Biology Program, Memorial Sloan Kettering Cancer Center, New York, NY, United States

3. Department of Pharmacology and Toxicology, University of Arizona, Tucson, AZ, United States

4. Department of Pharmacology, Weill Cornell Medical College, New York, NY, United States

5. Department of Physiology, Biophysics and Systems Biology, Weill Cornell Medical College, New York, NY, United States

KEYWORDS. Histones, ribose, glycation, click chemistry, epigenetics, proteomics

\section{Supporting Information}

A. Supplementary Figures
a. MS/MS of RiboLys adduct
b. MS/MS of Az-RiboLys adduct
c. Time-course
d. Histone Panel
e. Ribose in vitro time-dependent competition
f. Ribose in vitro dose-dependent competition
g. Ribose in cell dose-dependent competition
h. PTM analysis

B. Materials and Methods
a. Reagents and instrumentation
b. Synthesis of 5-azidoribose
c. Synthesis of 1-azidoribose
d. In vitro glycation
e. Nuclear glycation
f. Cellular glycation
g. Label free quantitative proteomic analyses of enriched nuclear extracts
h. Quantitation of ketoamine adducts in cells.

C. Tables and Schemes

D. NMR Spectra

E. References 


\section{A. Supplementary Figures}

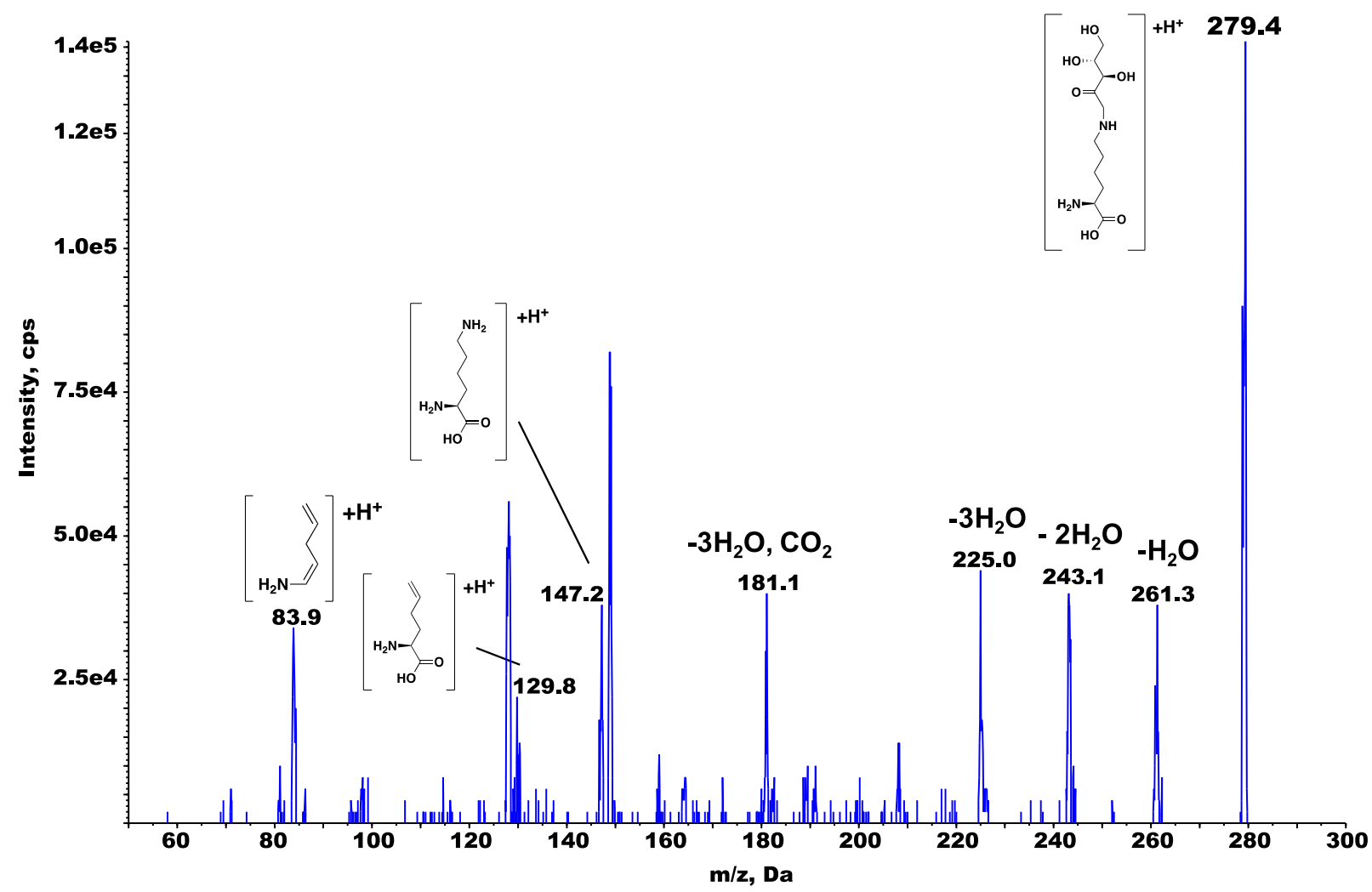

Figure S1. MS/MS of the RiboLys adduct. Equimolar concentrations (20 mM) of D-ribose and L-Lysine were incubated in PBS overnight at $37{ }^{\circ} \mathrm{C}$. The crude prep was then infused onto a 4500 QTRAP mass spectrometer in positive-ion mode. The fragments at 129.8 and $83.9 \mathrm{~m} / \mathrm{z}$ are diagnostic fragments for lysine modifications, consistent with our previous reports. ${ }^{1}$ 


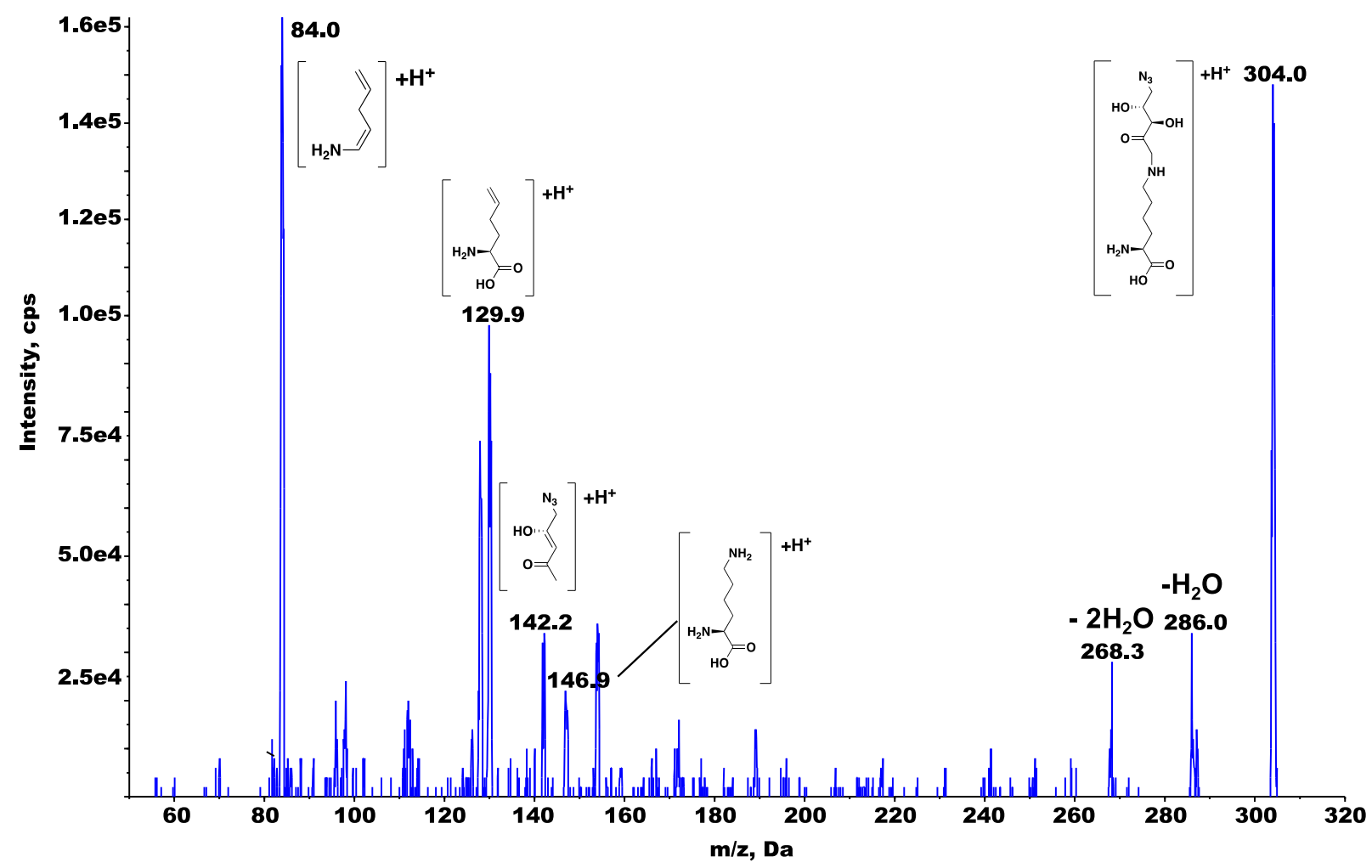

Figure S2. MS/MS of the Az-RiboLys adduct. Equimolar concentrations $(1 \mathrm{mM})$ of $\mathbf{5}$-AR and L-Lysine were incubated in PBS overnight at $37{ }^{\circ} \mathrm{C}$. The crude prep was then infused onto a 4500 QTRAP mass spectrometer in positive-ion mode. The fragments at 129.9 and $84.0 \mathrm{~m} / \mathrm{z}$ are diagnostic fragments for lysine modifications, consistent with our previous reports. ${ }^{1}$ 


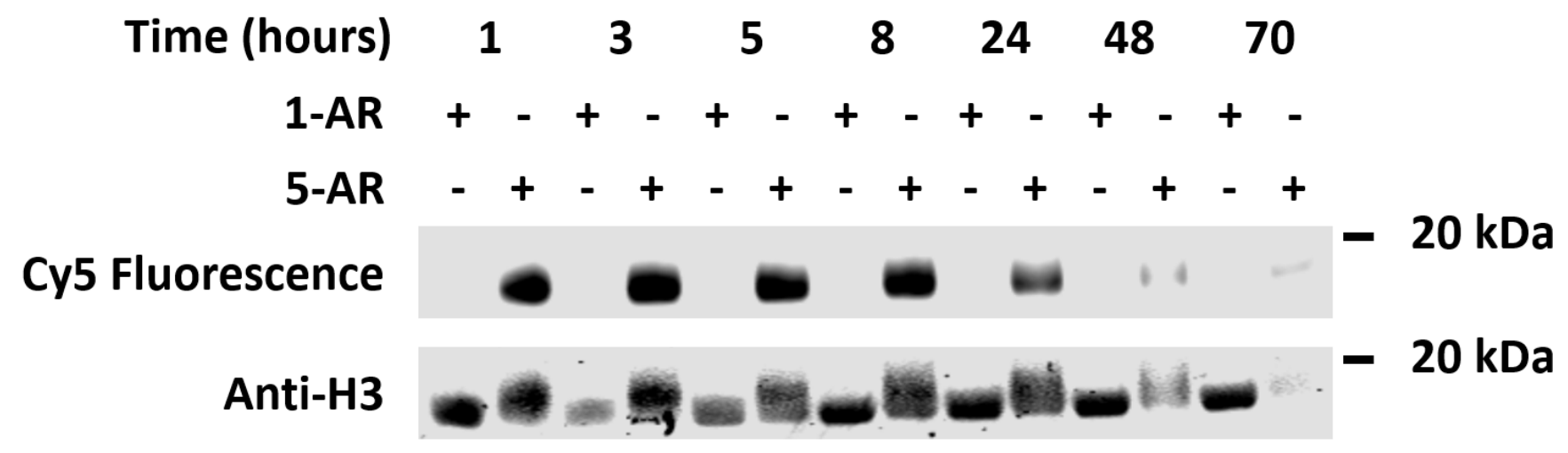

Figure S3. Time-course analysis of 5-AR glycation of recombinant histone H3 followed by DBCO Cy5 fluorescence labeling and western blot analysis using anti-H3. 


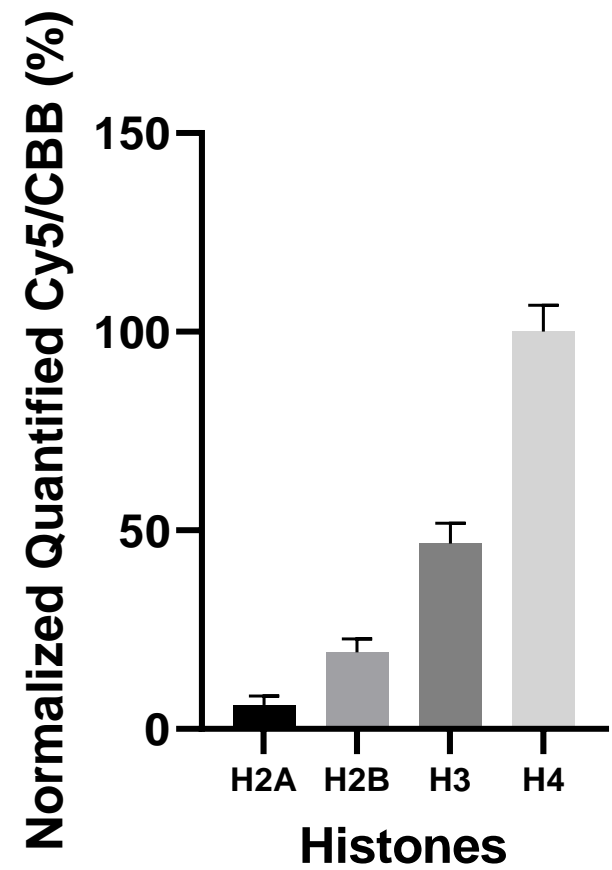

Figure S4. Quantification of side-by-side analyses of recombinant histones glycated with $5 \mathrm{mM}$ of 5-AR. Ratio of quantified Cy5 and CBB signals normalized and reported. Error bars depict S.E.M, N = 4 . 
A

Time (Hours)

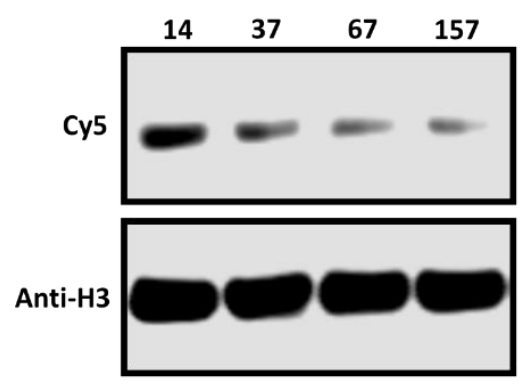

B

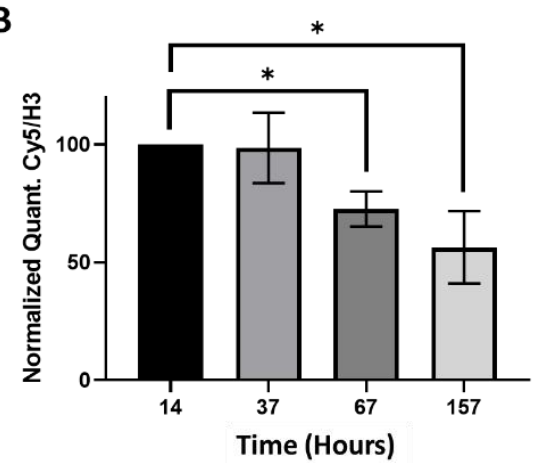

Figure S5. Time-dependent competition assay between ribose and 5-AR for the glycation of recombinant Histone H3. Histone $\mathrm{H} 3$ incubated with D-ribose and then with 5-AR followed by a click reaction with DBCO Cy5. (A) Representative blots of $\mathrm{Cy} 5$ fluorescence signal and Anti-H3 loading control. (B) Cy5 and $\mathrm{H} 3$ signals were quantified and normalized. $\mathrm{N}=3, *: p<0.05$. 


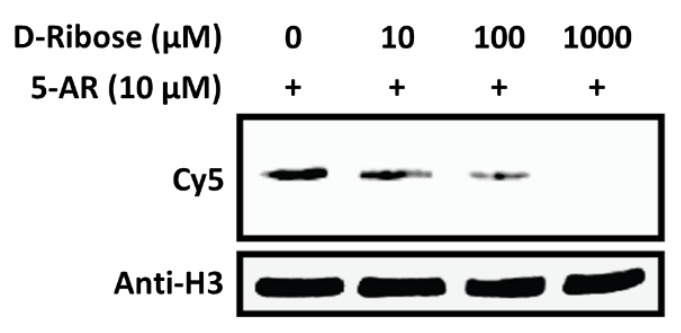

Figure S6. Ribose dose-dependent competition of AzRiboLys signal on H3 in vitro. Histone H3 was co-incubated with 5AR and increasing concentrations of D-ribose for 1 hour at $37{ }^{\circ} \mathrm{C}$ followed by click-labeling, SDS-PAGE separation, and fluorescence and western blot analyses. 


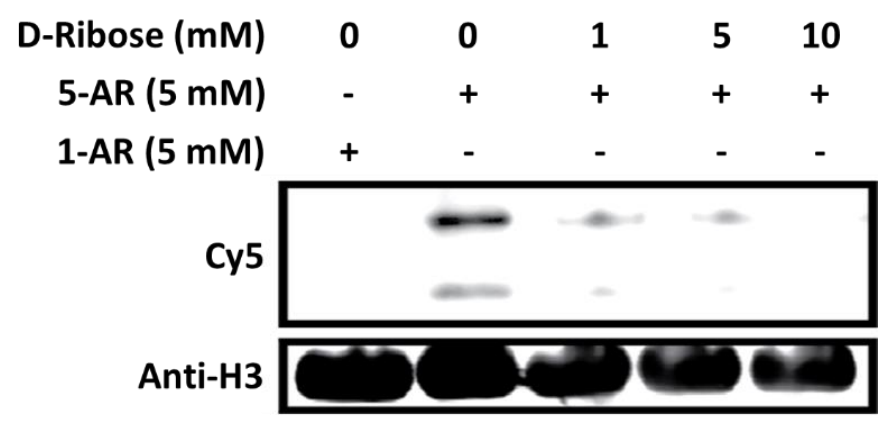

Figure S7. Ribose dose-dependent competition of AzRiboLys signal on histones in 293T cells. Cells were co-incubated with either 5-AR or 1-AR and increasing concentrations of D-ribose for 9 hours at $37^{\circ} \mathrm{C}$ before nuclei were isolated followed by click-labelling, SDS-PAGE separation, and fluorescence and western blot analyses. 

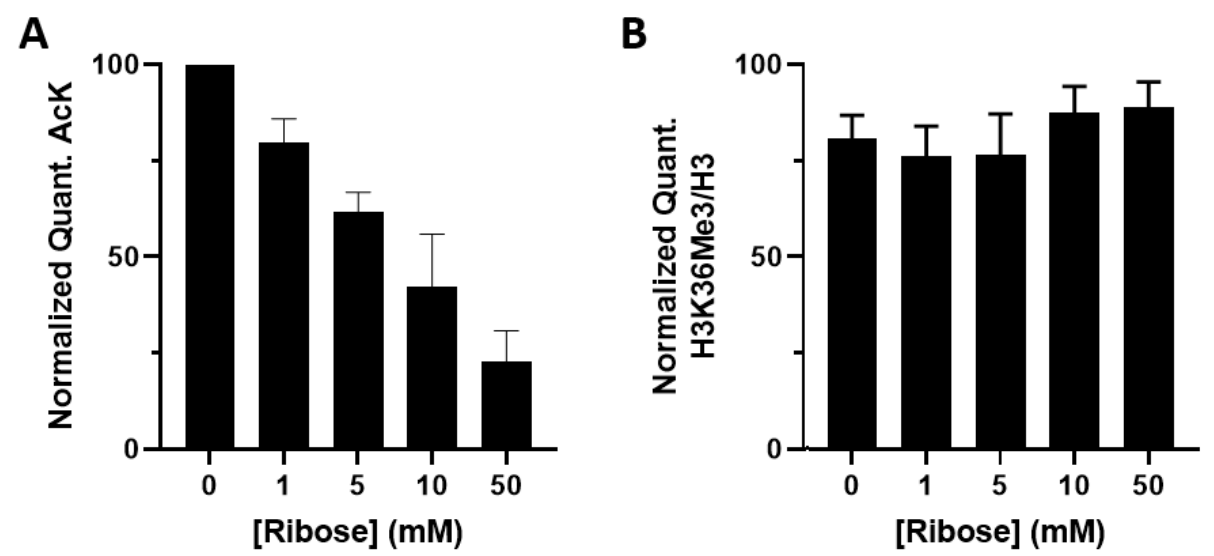

Figure S8. Quantification of changes in enzymatic PTMs on histones in response to ribose treatment of 293T cells. Cells were treated with increasing amounts of D-ribose followed by high salt extraction and western blot analyses with the following antibodies: (A) Anti-AcK; errors depict S.E.M, N=3. (B) Anti-H3K36Me ; errors depict S.E.M, N=4. 


\section{B. Materials and Methods}

\section{a. Reagents and Instrumentation}

Reagents were obtained from Aldrich Chemical, Acros Organics, or Fisher Scientific unless otherwise stated and used without further purification. NMR spectra were recorded on Bruker UltraShield Plus $600 \mathrm{MHz}$ Avance III NMR with DCH CryoProbe at $24{ }^{\circ} \mathrm{C}$ in the designated solvents. Chemical shifts are expressed in ppm relative to TMS $\left({ }^{1} \mathrm{H}, 0 \mathrm{ppm}\right)$ or solvent signals: $\mathrm{D}_{2} \mathrm{O}\left({ }^{1} \mathrm{H}, 4.79 \mathrm{ppm}\right), \mathrm{CDCl}_{3}\left({ }^{1} \mathrm{H}, 7.26 \mathrm{ppm},{ }^{13} \mathrm{C}, 77.16 \mathrm{ppm}\right)$; coupling constants are expressed in $\mathrm{Hz}$. NMR spectra were processed using Mnova (www.mestrelab.com/software/mnova-nmr) software. High-resolution mass spectra were obtained on a Waters Acuity Premiere XE TOF LC-MS by electrospray ionization (ESI). Biochemical reagents and cellular culture media were purchased from Fisher Scientific or Sigma Aldrich Corporation whilst antibodies were purchased according to Table 1 below. Immuno- and fluorescent-blots and gels were imaged on an Odyssey CLx Imaging System (LiCor). Perseus and Graphpad Prism were used for the analysis and representation of proteomics data.

\section{b. Synthesis of 5-azidoribose}

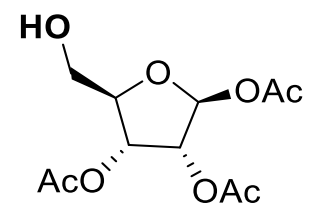

(1)

$(2 S, 3 R, 4 R, 5 R)$-5-(hydroxymethyl)tetrahydrofuran-2,3,4-triyl triacetate (1). A solution of commercially available $\beta$-Dribofuranose 1,2,3,4-tetraacetate (3.82 g, $12 \mathrm{mmol}, 1$ eq.) in DMF (30 mL) was diluted with $0.1 \mathrm{M}$ sodium phosphate buffer $(\mathrm{pH}=7.0 ; 270 \mathrm{~mL})$ and $C$. rugosa lipase $(5.93 \mathrm{~g}$, enzyme: substrate $=1.5: 1(\mathrm{w} / \mathrm{w}))$ was added. The mixture was stirred for 24 hours at room temperature and thin-layer chromatography (TLC), using diethyl ether as an eluent and potassium permanganate stain, was used to track product formation $(\mathrm{rf}=0.7)$. Solute was removed by vacuum filtration, and the filtrate was lyophilized in a freeze dryer. The resulting residue was resuspended in ethyl acetate $(500 \mathrm{~mL})$, vacuum filtered through celite, and the filtrate was concentrated under reduced pressure to yield a slightly yellow crude oil $(2.92 \mathrm{~g}, 10.54 \mathrm{mmol}, 87$ $\%) . \delta_{\mathrm{H}}\left(600 \mathrm{MHz}, \mathrm{CDCl}_{3}\right) 6.16(\mathrm{~s}, 1 \mathrm{H}), 5.41(\mathrm{dd}, J=7.2,4.9 \mathrm{~Hz}, 1 \mathrm{H}), 5.35(\mathrm{dd}, J=4.9,1.1 \mathrm{~Hz}, 1 \mathrm{H}), 4.26(\mathrm{dt}, J=7.2,3.6$ $\mathrm{Hz}, 1 \mathrm{H}), 3.86$ (ddd, $J=12.5,5.3,3.2 \mathrm{~Hz}, 1 \mathrm{H}), 3.66$ (ddd, $J=12.3,8.1,3.9 \mathrm{~Hz}, 1 \mathrm{H}), 2.11(\mathrm{~s}, 3 \mathrm{H}), 2.13(\mathrm{~s}, 3 \mathrm{H}), 2.08$ (s, 3H); $\delta_{\mathrm{C}}(150 \mathrm{MHz}, \mathrm{CDCl} 3) 170.14,169.60,169.33,98.31,82.43,74.66,69.88,61.96,20.69$. ESI-MS: Calcd for $\mathrm{C}_{11} \mathrm{H}_{16} \mathrm{O}_{8} \mathrm{Na}$ $\left([\mathrm{M}+\mathrm{Na}]^{+}\right): 299.0743$, Found: 299.0751 .

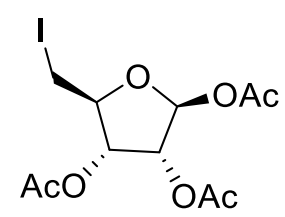

(2)

(2S,3R,4S,5S)-5-(iodomethyl)tetrahydrofuran-2,3,4-triyl triacetate (2). A mixture of 1 (3.67 g, $13.3 \mathrm{mmol}, 1 \mathrm{eq}$.), triphenylphosphine (6.98 g, $26.6 \mathrm{mmol}, 2$ eq.), imidazole (1.81 g, $26.6 \mathrm{mmol}, 2$ eq.) and iodine (4.73 g, $18.6 \mathrm{mmol}, 1.4 \mathrm{eq}$.) was dissolved in toluene $(45 \mathrm{~mL})$ in a round bottom flask and heated in a reflux apparatus at $80{ }^{\circ} \mathrm{C}$ for 8 hours. The toluene was removed under reduced pressure and the residue was resuspended in water $(40 \mathrm{~mL})$ and ethyl acetate $(100 \mathrm{~mL})$ and separated using a separatory funnel. The aqueous layer was extracted three times using ethyl acetate $(100 \mathrm{~mL})$ and the combined organic fraction was washed with sodium thiosulfate pentahydrate solution $(50 \mathrm{~mL})$ followed by saturated brine $(50 \mathrm{~mL})$. The separated product was dried over sodium sulfate, filtered and finally concentrated under reduced pressure to yield a crude red oil. The crude oil was further purified on a silica column in 30-100\% ethyl acetate gradient in hexanes to yield the desired product $(1.90 \mathrm{~g}, 4.92 \mathrm{mmol}, 37 \%)$. $\delta_{\mathrm{H}}\left(600 \mathrm{MHz}, \mathrm{CDCl}_{3}\right) 6.15(\mathrm{~s}, 1 \mathrm{H}), 5.37(\mathrm{~d}, J=4.8 \mathrm{~Hz}, 1 \mathrm{H}), 5.29(\mathrm{dd}$, $J=7.1,4.8 \mathrm{~Hz}, 1 \mathrm{H}), 4.23(\mathrm{dt}, J=7.1,5.7 \mathrm{~Hz}, 1 \mathrm{H}), 3.36-3.32(\mathrm{~m}, 2 \mathrm{H}), 2.12(\mathrm{~d}, J=6.3 \mathrm{~Hz}, 6 \mathrm{H}), 2.09(\mathrm{~s}, 3 \mathrm{H}) ; \delta_{\mathrm{C}}(150 \mathrm{MHz}$, CDCl3) 169.72, 169.55, 169.17, 98.01, 74.68, 73.94, 21.26, 20.75, 20.67, 5.65. ESI-MS: Calcd for $\mathrm{C}_{11} \mathrm{H}_{15} \mathrm{O}_{7} \mathrm{NaI}\left([\mathrm{M}+\mathrm{Na}]^{+}\right)$: 408.9760, Found: 408.9764. 


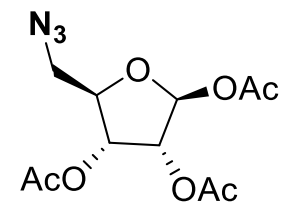

(3)

$(\mathbf{2 S , 3 R , 4 R , 5 R ) - 5 - ( a z i d o m e t h y l ) t e t r a h y d r o f u r a n - 2 , 3 , 4 - t r i y l ~ t r i a c e t a t e ~ ( 3 ) . ~ A ~ s t i r r i n g ~ s o l u t i o n ~ o f ~} 2$ (850 $\mathrm{mg}, 2.20 \mathrm{mmol}, 1$ eq.), and sodium azide (429.4 mg, $6.61 \mathrm{mmol}, 3$ eq.) in DMF $(10 \mathrm{~mL})$ in a round bottom flask was heated in a reflux apparatus at $70{ }^{\circ} \mathrm{C}$ for 3 hours. Then, the reaction was diluted with ethyl acetate $(60 \mathrm{~mL})$ and water $(20 \mathrm{~mL})$, separated using a separatory funnel before the aqueous layer was extracted three times using ethyl acetate $(60 \mathrm{~mL})$. The combined organic fractions were washed twice with water $(30 \mathrm{~mL})$ and once with saturated brine $(30 \mathrm{~mL})$ before being dried over sodium sulfate, filtered, and concentrated under reduced pressure to yield the desired product ( $660 \mathrm{mg}, 2.19 \mathrm{mmol}$, quantitative). $\delta_{\mathrm{H}}$ $\left(600 \mathrm{MHz}, \mathrm{CDCl}_{3}\right) 6.17(\mathrm{~s}, 1 \mathrm{H}), 5.42(\mathrm{dd}, J=7.4,4.8 \mathrm{~Hz}, 1 \mathrm{H}), 5.37(\mathrm{~d}, J=4.8 \mathrm{~Hz}, 1 \mathrm{H}), 4.32(\mathrm{dt}, J=7.4,3.7 \mathrm{~Hz}, 1 \mathrm{H}), 3.66$ $(\mathrm{dd}, J=13.5,3.4 \mathrm{~Hz}, 1 \mathrm{H}), 3.28(\mathrm{dd}, J=13.6,4.1 \mathrm{~Hz}, 1 \mathrm{H}), 2.13(\mathrm{~d}, J=5.2 \mathrm{~Hz}, 6 \mathrm{H}), 2.07(\mathrm{~s}, 3 \mathrm{H}) ; \delta_{\mathrm{C}}(150 \mathrm{MHz}, \mathrm{CDCl} 3)$ 169.84, 169.55, 169.33, 98.15, 74.41, 70.45, 51.53, 21.18, 20.68, 20.63. ESI-MS: Calcd for $\mathrm{C}_{11} \mathrm{H}_{15} \mathrm{~N}_{3} \mathrm{O}_{7} \mathrm{Na}_{(}\left(\mathrm{M}_{+} \mathrm{Na}^{+}\right)$: 324.0808, Found: 324.0800 .

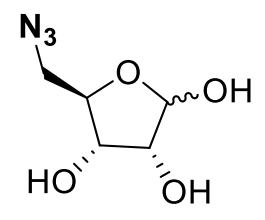

(4)

$(\mathbf{2} R, 3 R, 4 S, 5 R)-5$-(azidomethyl)tetrahydrofuran-2,3,4-triol (4). A solution of $20 \mathrm{mM}$ sodium methoxide in methanol (10 $\mathrm{mL}, 0.2 \mathrm{mmol}, 0.189$ eq.) was added to $3(319 \mathrm{mg}, 1.06 \mathrm{mmol}, 1$ eq.) in a reaction vial and stirred for 1 hour at room temperature. The reaction was tracked by TLC $(\mathrm{rf}=0.1)$ using a 50:50 mixture of ethyl acetate in hexanes and visualized by potassium permanganate staining. Dowex resin was used to quench the reaction and neutralize the $\mathrm{pH}$ to 7 . The mixture was filtered and concentrated under reduced pressure to yield the desired product as a colorless oil (147 $\mathrm{mg}, 0.837 \mathrm{mmol}, 79 \%$ ). The $\alpha-\beta$ ratio was determined to be approximately $1: 2$ (by integration of the ${ }^{1} \mathrm{H}-\mathrm{NMR}$ spectrum); $\delta_{\mathrm{H}}\left(600 \mathrm{MHz}, \mathrm{D}_{2} \mathrm{O}\right) 5.39$ $(\mathrm{d}, J=4.0 \mathrm{~Hz}, 1 \mathrm{H}, \mathrm{H}-1 \alpha), 5.23(\mathrm{~d}, J=1.5 \mathrm{~Hz}, 2 \mathrm{H}, \mathrm{H}-1 \beta), 4.24(\mathrm{dd}, J=7.0,4.7 \mathrm{~Hz}, 2 \mathrm{H}), 4.20-4.15(\mathrm{~m}, 1 \mathrm{H}), 4.11(\mathrm{dd}, J=$ 5.6, $4.0 \mathrm{~Hz}, 1 \mathrm{H}), 4.08-4.01(\mathrm{~m}, 3 \mathrm{H}), 3.99(\mathrm{dd}, J=4.7,1.5 \mathrm{~Hz}, 2 \mathrm{H}), 3.67-3.59(\mathrm{~m}, 3 \mathrm{H}), 3.38$ (ddd, $J=13.5,5.5,3.4 \mathrm{~Hz}$, $3 \mathrm{H}) ; \delta_{\mathrm{C}}\left(150 \mathrm{MHz}, \mathrm{D}_{2} \mathrm{O}\right) 101.12,96.39,80.96,80.57,75.01,70.91,70.67,70.62,52.41,51.72$. ESI-MS: 5-AR-DBCO Cy5 Calcd for $\mathrm{C}_{57} \mathrm{H}_{65} \mathrm{~N}_{7} \mathrm{O}_{15} \mathrm{NaS}_{3}\left([\mathrm{M}+\mathrm{Na}]^{+}\right)$: 1206.3599, Found: 1206.3553 . FT-IR (ATR ZnSe) $2105.30 \mathrm{~cm}^{-1}$ (azide stretch).

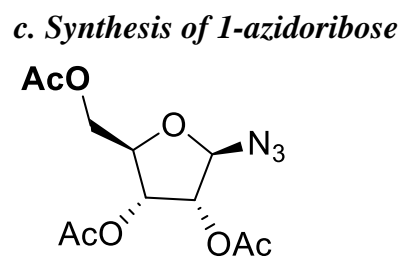

(5)

$(2 R, 3 R, 4 S, 5 R)-2$-(acetoxymethyl)-5-azidotetrahydrofuran-3,4-diyl diacetate (5). To a solution of commercially available $\beta$-D-ribofuranose 1,2,3,4-tetraacetate ( $1 \mathrm{~g}, 3.14 \mathrm{mmol}, 1$ eq.) in dichloromethane $(10 \mathrm{~mL})$, tri-methyl silyl azide $(620 \mu \mathrm{L}, 4.71 \mathrm{mmol}, 1.5 \mathrm{eq}$.) and boron trifluoro etherate $(390 \mu \mathrm{L}, 3.14 \mathrm{mmol}, 1$ eq. $)$ were added. The reaction was stirred for 2 hours at room temperature after which the solvent was removed under reduced pressure and the remaining residue was resuspended in ethyl acetate and water. The mixture was separated using a separatory funnel, and the aqueous layer was extracted three times using ethyl acetate. The combined organic layers were washed twice with water, once with brine and dried using anhydrous sodium sulfate. After filtration, the product was concentrated under reduced pressure to yield the desired product $(913 \mathrm{mg}, 3.03 \mathrm{mmol}, 97 \%) . \delta_{\mathrm{H}}\left(600 \mathrm{MHz}, \mathrm{CDCl}_{3}\right) 5.37(\mathrm{~d}, J=2.0 \mathrm{~Hz}, 1 \mathrm{H}), 5.34(\mathrm{dd}, J=6.8,4.8 \mathrm{~Hz}, 1 \mathrm{H})$, $5.14(\mathrm{dd}, J=4.8,2.0 \mathrm{~Hz}, 1 \mathrm{H}), 4.42(\mathrm{dd}, J=12.2,3.2 \mathrm{~Hz}, 1 \mathrm{H}), 4.35(\mathrm{ddd}, J=7.2,4.3,3.2 \mathrm{~Hz}, 1 \mathrm{H}), 4.15(\mathrm{dd}, J=12.2,4.3$ $\mathrm{Hz}, 1 \mathrm{H}), 2.13$ (d, $J=4.2 \mathrm{~Hz}, 6 \mathrm{H}), 2.07$ (s, 3H); $\delta_{\mathrm{C}}(150 \mathrm{MHz}, \mathrm{CDCl} 3)$ 170.78, 169.72, 169.59, 92.78, 79.48, 70.57, 63.14, 20.86, 20.69, 20.64. ESI-MS: Calcd for $\mathrm{C}_{11} \mathrm{H}_{15} \mathrm{~N}_{3} \mathrm{O}_{7} \mathrm{Na}\left([\mathrm{M}+\mathrm{Na}]^{+}\right)$: 324.0808, Found: 324.0797. 


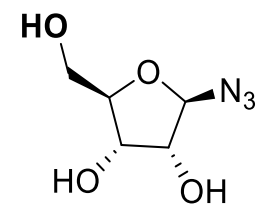

(6)

$(2 R, 3 R, 4 S, 5 R)$-2-azido-5-(hydroxymethyl)tetrahydrofuran-3,4-diol (6). A solution of $20 \mathrm{mM}$ sodium methoxide in methanol (10 mL, $0.2 \mathrm{mmol}, 0.0660$ eq.) was added to 5 (913 mg, $3.03 \mathrm{mmol}, 1$ eq.) in a reaction vial and stirred for 30 minutes at room temperature. Dowex resin was added to quench the reaction and the mixture was filtered and concentrated under reduced pressure to yield a colorless oil $(514 \mathrm{mg}, 2.93 \mathrm{mmol}, 97 \%)$. $\delta_{\mathrm{H}}\left(600 \mathrm{MHz}, \mathrm{D}_{2} \mathrm{O}\right) 5.34(\mathrm{~d}, J=1.9 \mathrm{~Hz}, 1 \mathrm{H})$, $4.17(\mathrm{dd}, J=6.9,4.6 \mathrm{~Hz}, 1 \mathrm{H}), 4.02(\mathrm{ddd}, J=7.1,5.9,3.1 \mathrm{~Hz}, 1 \mathrm{H}), 3.96(\mathrm{dd}, J=4.8,2.0 \mathrm{~Hz}, 1 \mathrm{H}), 3.81(\mathrm{dd}, J=12.6,3.1 \mathrm{~Hz}$, $1 \mathrm{H}), 3.64(\mathrm{ddd}, J=12.6,5.8,0.9 \mathrm{~Hz}, 1 \mathrm{H}) ; \delta_{\mathrm{C}}\left(150 \mathrm{MHz}, \mathrm{D}_{2} \mathrm{O}\right) 94.49,83.31,74.49,70.01,61.71$. ESI-MS: 1-AR-DBCO Cy5 Calcd for $\mathrm{C}_{57} \mathrm{H}_{65} \mathrm{~N}_{7} \mathrm{O}_{15} \mathrm{NaS}_{3}\left([\mathrm{M}+\mathrm{Na}]^{+}\right)$: 1206.3599 , Found: 1206.3555 . FT-IR (ATR ZnSe) $2113.64 \mathrm{~cm}^{-1}$ (azide stretch).

\section{d. In vitro glycation}

Recombinant Histone Expression and Purification. Recombinant human canonical core histones H2A, H2B, H3, and H4 were expressed in E. coli BL21 (DE3) or E. coli C41 (DE3), extracted from inclusion bodies by guanidine hydrochloride, and purified by flash reverse chromatography or semipreparative HPLC as previously described..$^{2-3}$ The purity of the histones was confirmed by SDS-PAGE and RP-LC-ESI-MS.

Glycation and labeling of recombinant histones. A $10 \mu \mathrm{L}$ reaction containing $20 \mu \mathrm{M}$ of the designated histone (H2A, $\mathrm{H} 2 \mathrm{~B}, \mathrm{H} 3$, or $\mathrm{H} 4$ ) and $5 \mathrm{mM}$ of either D-ribose, 1-AR or 5-AR in PBS was allowed to react for 8 hours at $37^{\circ} \mathrm{C}$. Thereafter, $5 \mu \mathrm{L}$ of $0.1 \mathrm{mM}$ DBCO Cy5 in PBS was added and the reactions were incubated for 3 hours at $37^{\circ} \mathrm{C}$. Sample buffer was then added and the reactions were separated by SDS-PAGE followed by transfer onto polyvinylidene difluoride (PVDF) membrane and subjected to western blot analysis using anti-H3 antibody (see Table S1).

Time-course of 5-AR-glycation of recombinant histones. Two $100 \mu \mathrm{L}$ reactions containing $20 \mu \mathrm{M}$ of histone H3 and 5 $\mathrm{mM}$ of either $\mathbf{5 - A R}$ or 1-AR were incubated at $37^{\circ} \mathrm{C}$. At various time-points throughout the incubation, $10 \mu \mathrm{L}$ aliquots were removed and stored at $-80{ }^{\circ} \mathrm{C}$ until all samples had been collected. To each thawed aliquot was added $5 \mu \mathrm{L}$ of $100 \mu \mathrm{M}$ DBCO Cy5 in PBS and the reactions were incubated for 3 hours at $37^{\circ} \mathrm{C}$. Sample buffer was added and the reactions were separated by SDS-PAGE, transferred onto PVDF membrane, and then subjected to fluorescence imaging and subsequent western blot analysis using anti-H3 antibody (see Table S1).

Ribose time-dependent competition of 5-AR labeling. A $100 \mu \mathrm{L}$ reaction containing $20 \mu \mathrm{M}$ of histone $\mathrm{H} 3$ and $100 \mu \mathrm{M}$ D-ribose was incubated at $37^{\circ} \mathrm{C}$. At various time-points throughout the incubation, $10 \mu \mathrm{L}$ aliquots were removed and stored at $-80{ }^{\circ} \mathrm{C}$ until all samples had been collected. To each thawed aliquot was then added $3 \mu \mathrm{L}$ of $857 \mu \mathrm{M}$ 5-AR solution and the reactions were incubated for 1 hour at $37^{\circ} \mathrm{C}$. Thereafter, $2 \mu \mathrm{L}$ of $20 \mu \mathrm{M}$ DBCO Cy5 was added and the reactions were incubated for a further 3 hours at $37{ }^{\circ} \mathrm{C}$. Then, sample buffer was added and the reactions were separated by SDS-PAGE followed by transfer onto PVDF membrane, and then subjected to fluorescence imaging and subsequent western blot analysis using anti-H3 antibody (see Table S1). Signals were quantified and normalized for Cy5 and H3. Differences relative to $\mathrm{t}=$ 14 hours were evaluated via unpaired one-tailed Student's $t$-test.

Ribose dose-dependent competition of 5-AR labeling. A $10 \mu \mathrm{L}$ reaction containing $20 \mu \mathrm{M}$ of histone $\mathrm{H} 3,10 \mu \mathrm{M}$ of 5-AR and $0,10,100$, or $1000 \mu \mathrm{M}$ of D-Ribose was incubated for 1 hour $37^{\circ} \mathrm{C}$ before $5 \mathrm{uL}$ of $0.2 \mu \mathrm{M}$ DBCO Cy5 was added and the modified reaction incubated for an additional 3 hours at $37^{\circ} \mathrm{C}$. Then, sample buffer was added and the reactions were separated by SDS-PAGE followed by transfer onto PVDF membrane, and then subjected to fluorescence imaging and subsequent western blot analysis using an anti-H3 antibody (see Table S1).

\section{e. Nuclear glycation}

Nucleus isolation from 293T Human Embryonic Kidney Cells (HEK 293T). As previously reported, frozen cell pellets ( 10 million cells) were thawed on ice and resuspended in $1 \mathrm{~mL}$ of hypotonic resuspension buffer $(10 \mathrm{mM}$ Tris $\mathrm{pH} 7.5,15$ $\mathrm{mM}$ sodium chloride, $1.5 \mathrm{mM}$ magnesium chloride, and protease inhibitor) and incubated on ice for 10 minutes. ${ }^{4} \mathrm{Next}$, the 
nuclei were separated by centrifugation $\left(450 \mathrm{~g}, 5\right.$ minutes, $\left.4{ }^{\circ} \mathrm{C}\right)$ and washed again with resuspension buffer. The nuclei were then washed in $500 \mu \mathrm{L}$ and resuspended in $100 \mu \mathrm{L}$ of modified buffer A (20 mM Hepes pH 7, $1.5 \mathrm{mM}$ magnesium chloride, $150 \mathrm{mM}$ potassium chloride, $1 \mathrm{mM}$ dithiothreitol, $1 \mathrm{mg} / \mathrm{mL}$ of bovine serum albumin, $1 \mathrm{mM}$ of ATP, and protease inhibitor).

Glycation and Labeling of 293T Nuclei. Isolated nuclei in $25 \mu \mathrm{L}$ of modified buffer A were incubated with $2.5 \mu \mathrm{L}$ of PBS, $50 \mathrm{mM}$ of D-ribose, 1-AR or 5-AR at $37^{\circ} \mathrm{C}$ for 8 hours. Thereafter, the nuclei were separated by centrifugation and washed in $100 \mu \mathrm{L}$ of resuspension buffer twice before being resuspended in $20 \mu \mathrm{L}$ of $20 \mu \mathrm{M} \mathrm{DBCO} \mathrm{Cy5}$ and incubated at $37{ }^{\circ} \mathrm{C}$ for 3 hours. The nuclei were then washed with PBS and lysed by sonication. Sample buffer was then added, and the reactions were separated by SDS-PAGE followed by transfer onto PVDF membranes for further imaging and western blot analyses using anti-H3 antibody (see Table S1).

\section{f. Cellular glycation}

Glycation and Labeling of Nuclear Proteins in Live 293T Cells. Cells were cultured to $60 \%$ confluency on a 6-well plate before being treated with media containing PBS, D-ribose $(5 \mathrm{mM}), \mathbf{1 - A R}(5 \mathrm{mM})$, or $\mathbf{5}-\mathbf{A R}(5 \mathrm{mM})$ for 8 hours at $37{ }^{\circ} \mathrm{C}$. Cells were harvested and nuclei were isolated as described above before being incubated in modified buffer A with $20 \mu \mathrm{M}$ of DBCO Cy 5 for 3 hours at $37^{\circ} \mathrm{C}$. The nuclei were then washed with PBS and lysed by sonication. Sample buffer was then added, reactions were separated by SDS-PAGE followed by western blot analysis using anti-H3 antibody (see Table S1).

Ribose dose-dependent competition of 5-AR labeling. Cells were cultured to $60 \%$ confluency on a 6-well plate before being treated with media containing 1-AR or 5-AR alone, or 5-AR with 1, 5, or $10 \mathrm{mM}$ of D-ribose, for 9 hours at $37{ }^{\circ} \mathbf{C}$. Cells were harvested and nuclei were isolated as described above before being incubated in modified buffer A with $20 \mu \mathrm{M}$ of DBCO Cy5 for 3 hours at $37{ }^{\circ} \mathrm{C}$. The nuclei were then washed with PBS and lysed by sonication. Sample buffer was then added, reactions were separated by SDS-PAGE followed by western blot analysis using anti-H3 antibody (see Table S1).

Histone Ribose Glycation PTM Analysis in 293T Cells. Cells were cultured in media infused with increasing concentrations of D-ribose $(0 \mathrm{mM}, 1 \mathrm{mM}, 5 \mathrm{mM}, 10 \mathrm{mM}$, and $50 \mathrm{mM})$ on a $10-\mathrm{cm}$ plate for 48 hours with media change after 24 hours. After harvesting the cells, the soluble nuclear and cytosolic fractions were removed using Nuclear and Cytoplasmic Extraction Reagents (Thermo Fisher Scientific) according to the manufacturer's protocol. Histones were extracted using a previously described high salt extraction protocol and separated by SDS-PAGE followed by western blot using, anti-H3, anti-H3K9Me 2 , anti-acetyl Lysine, and anti-H3K36 Me 3 (see Table S1). ${ }^{5}$

Deglycation by FN3K in Live Cells. The FN3K gene was amplified from the human cDNA library (Wendel lab at MSKCC) by PCR. ${ }^{6}$ The primers used were 5'-GCGGCCGCGACTACAAAGACGATGACGACAAGATGGAGCAGCTGCTGCGC3' (forward) and 5'-GGTACCCTACTTGAGCAGCCTTCG-3' (reverse). The purified PCR product was inserted into the pCMV plasmid by restriction endonuclease cloning. HEK 293T cells were transfected with the resulting pCMV-FN3K-Flag using the Lipofectamine 2000 Transfection Reagent (Thermo Fisher Scientific) according to the manufacturer's protocol. After 24 hours, transfected and non-transfected cells were split onto 6-well plates and incubated with 5 mM of 5-ARsupplemented media for 12 hours before being harvested. Cells were lysed and both the initial resuspension buffer lysis and the nuclei were labeled with $20 \mu \mathrm{M}$ of DBCO Cy5 for 3 hours at $37^{\circ} \mathrm{C}$. Next, both sets of samples were sonicated and separated by SDS-PAGE followed by western blot analysis using anti-H3, anti-FN3K, and anti-Actin antibodies (see Table S1).

\section{g. Label-free quantitative proteomic analysis of enriched nuclear extracts}

Cy5-handle-facilitated Enrichment of Glycated Nuclear Extracts. Nuclei (5 million cells per sample) were isolated, glycated and labeled with DBCO Cy5 as described above with some notable differences. After removing the excess click reagent and washing with PBS, the beads were resuspended in $100 \mu \mathrm{L}$ of RIPA buffer (PBS pH 7.5, $1 \%$ NP-40. $0.5 \%$ weight/volume sodium deoxycholate, $0.1 \%$ SDS) and lysed by sonication. Next, nuclear lysates were incubated with Dynabeads Protein G (Thermo Fisher Scientific) reversibly bound to anti-Cy5 (20 $\mu \mathrm{L}$ of beads with $2 \mu \mathrm{L}$ of $1.5 \mathrm{mg} / \mathrm{mL}$ antiCy5 (Sigma C1117) per sample) for 1 hour on ice. The beads were then washed three times with RIPA buffer and twice with PBS before enrichment evaluation or proteomics analyses (see below). On-bead enrichment evaluation samples were boiled in sample buffer, then, inputs, flow-through, and denatured beads were separated by SDS-PAGE, imaged by in gel- 
fluorescence and subjected to western blot analysis using anti-H3, anti-BMI-1, and anti-SMARCC1/BAF155 antibodies (see Table S1).

LFQ Sample Preparation and Analysis. Three biological replicates of nuclear lysates were incubated with 1-AR or 5-AR, labeled with DBCO Cy5, and enriched as described above. The proteins were subjected to on-bead digestion using sequencing grade modified trypsin (Promega) for 3.5 hours. The supernatant was withdrawn and reduced/alkylated with DTT/IAA. A second round of tryptic digestion was carried out overnight. Peptides were analyzed using a Dionex 3000 Ultimate HPLC equipped with a NCS3500RS nano- and microflow pump (Dionex). Peptides were loaded onto a $100 \mu \mathrm{m} x$ 20 mm Acclaim PepMap C18 trap column (Thermo Fisher Scientific). A 70-minute linear gradient was applied across a 75 $\mu \mathrm{m}$ x $120 \mathrm{~mm}$ pulled-emitter nanocolumn (Nikkyo Technos). Peptides were analyzed using a Q-Exactive HF mass spectrometer (Thermo Fisher Scientific). Data was recorded in positive mode with Top 20 DDA acquisition. Data analysis was performed with the MaxQuant software. ${ }^{7}$ Oxidation of methionine and acetylation of protein N-termini were set as dynamic modifications, carbamidomethylation of cysteine was set as a static modification, and standard settings were applied. The search results from MaxQuant were analyzed by Perseus. ${ }^{8}$ Briefly, the control 1-AR and 5-AR-labeled sample replicates were grouped correspondingly. Protein abundances were measured using iBAQ intensities and were $\log _{2}$ transformed. Missing values were imputed with random numbers from a normal distribution, whose mean and standard deviation were chosen to best simulate low abundance values below the noise level (replaced missing values by normal distribution width $=0.3$ and shift $=2.2$ ). An FDR Student's $t$-test (FDR 0.05) was applied to test for significance, the resulting table was exported as Data Set S1 and is represented in the volcano plot, with difference in iBAQ values between 1-ARand 5-AR- treated samples plotted on the $\mathrm{x}$-axis and the $-\log _{10}$ of the significance from the $t$-test, plotted on the $\mathrm{y}$-axis (Figure 3C). Only entries that were identified in all 5-AR-labeled sample replicates, with more than two unique peptides, and with $P$ values smaller than 0.05 , were subjected to subsequent ontology analyses (Data Set S2). From this data, a gene list was extracted (Gene List 1) and submitted for function gene ontology analysis using the GOrilla web-based tool against a total HEK-293T proteome. ${ }^{9}$ The resulting binding protein data were sorted by their FDR $q$-values and are reported (Figure 3E).

\section{h. Quantitation of ketoamine adducts in cells.}

Chromatin Isolation: Cells were cultured in media infused with increasing concentrations of D-ribose $(0 \mathrm{mM}, 1 \mathrm{mM}, 5$ $\mathrm{mM}, 10 \mathrm{mM}$, and $50 \mathrm{mM}), \mathbf{5 - A R}(5 \mathrm{mM})$, or 1-AR $(5 \mathrm{mM})$ on $10-\mathrm{cm}$ plates for 8 hours before being harvested and pellets frozen at $-80^{\circ} \mathrm{C}$. Cell pellets were lysed in $250 \mu \mathrm{L}$ of a buffer containing $10 \mathrm{mM} \mathrm{HEPES} / \mathrm{KOH}, \mathrm{pH} 7.9,1.5 \mathrm{mM} \mathrm{MgCl} 2$, $10 \mathrm{mM} \mathrm{KCl}, 0.5 \%$ Igepal, $5 \mathrm{mM} \mathrm{NaB}$, and protease and phosphatase inhibitor cocktails (1:500 v/v, Sigma Aldrich, St. Louis, MO). Samples were incubated for $30 \mathrm{~min}$ on ice and nuclei were isolated via centrifugation $\left(1000 \mathrm{x} \mathrm{g}, 10 \mathrm{minutes}, 4{ }^{\circ} \mathrm{C}\right)$. Nuclear pellets were resuspended in $300 \mu \mathrm{L}$ of a buffer containing $20 \mathrm{mM} \mathrm{HEPES} / \mathrm{KOH} \mathrm{pH}=7.9,1.5 \mathrm{mM} \mathrm{MgCl}_{2}, 420 \mathrm{mM}$ $\mathrm{KCl}, 0.2 \mathrm{mM}$ EDTA, $25 \%$ glycerol, $5 \mathrm{mM} \mathrm{NaB}$, and protease and phosphatase inhibitor cocktails (1:500 v/v) and rotated end-over-end at $4^{\circ} \mathrm{C}$ for $16 \mathrm{~h}$. Chromatin was isolated via centrifugation $\left(1000 \mathrm{x} \mathrm{g}, 20\right.$ minutes, $\left.4^{\circ} \mathrm{C}\right)$, resuspended in 200

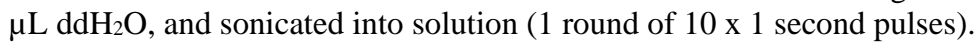

Quantification of RiboLys and Az-RiboLys using QuARKMod: $50 \mu \mathrm{g}$ of chromatin was precipitated with ice cold acetonitrile $(500 \mu \mathrm{L})$ for 2 hours at $-20^{\circ} \mathrm{C}$. Protein was pelleted via centrifugation at $14,000 \times \mathrm{g}$ for $10 \mathrm{~min}$ at $4{ }^{\circ} \mathrm{C}$ and the supernatant was aspirated. Chromatin pellets were then digested via sequential overnight incubations at $37{ }^{\circ} \mathrm{C}$ with sequencing grade-trypsin (Promega, Madison, WI) and Aminopeptidase M (Millipore, Burlington, MA) containing isotopic standards as previously described. ${ }^{1} 200 \mathrm{mM}$ heptofluorobutyric acid was then added and digested samples were analyzed on a Samples were chromatographed using a Shimadzu LC system equipped with a $150 \mathrm{x} 2.1 \mathrm{~mm}, 3.5 \mu \mathrm{m}$ particle diameter Eclipse XDB-C8 column (Agilent, Santa Clara, CA) at a flow rate of $0.425 \mathrm{~mL} / \mathrm{min}$. Mobile phase A: $0.1 \% \mathrm{HFBA}$ in water; mobile phase B: $0.1 \%$ HFBA in ACN. The following gradient was used: 0.5 min, $5 \%$ B; 8 min, $50 \%$ B; 8.5 min, $80 \%$ B; $9 \min 80 \% \mathrm{~B} ; 9.5 \mathrm{~min}, 5 \% \mathrm{~B}$. The column was equilibrated for 2 min at $5 \% \mathrm{~B}$. Scheduled MRM was conducted in positive mode using an AB SCIEX 4500 QTRAP. The MRM detection window was $90 \mathrm{sec}$ with a target scan time of 0.8 sec. The parameters used for detection are shown in Table $\mathbf{S 2}$ and RiboLys was quantified against CEL-d 4. 


\section{B. Tables and Schemes}

Table S1. Antibody List

\begin{tabular}{|c|c|c|}
\hline Antibody & Manufacturer & Catalog Number \\
\hline Cy5 & Sigma-Aldrich & $\mathrm{C} 1117$ \\
\hline H3 & Cell Signaling Technology & $14269 \mathrm{~S}$ \\
\hline Pan-acetyl Lysine & Cell Signaling Technology & $9441 S$ \\
\hline $\mathrm{H} 3 \mathrm{~K} 9 \mathrm{Me}_{2}$ & Abcam & ab1220 \\
\hline $\mathrm{H} 3 \mathrm{~K}_{3} 6 \mathrm{Me}_{3}$ & Abcam & ab9050 \\
\hline SMARCC1/BAF155 & Cell Signaling Technology & $12854 \mathrm{~T}$ \\
\hline BMI-1 & Cell Signaling Technology & $6964 S$ \\
\hline FN3K & Abcam & ab201201 \\
\hline Actin & Cell Signaling Technology & $4967 \mathrm{~S}$ \\
\hline
\end{tabular}

Table S2. MRM Parameters

\begin{tabular}{lcccc}
\hline \multicolumn{1}{c}{ Species } & Q1 $(\boldsymbol{m} / z)$ & Q3 $(\boldsymbol{m} / z)$ & Time $(\mathbf{m i n})$ & CE $(\mathbf{V})$ \\
\hline Lys & 147.1 & 84.1 & 4.7 & 29 \\
${ }^{13} \mathrm{C}_{6}{ }^{15} \mathrm{~N}_{2}$ Lys & 155.1 & 90.1 & 4.7 & 29 \\
$\mathrm{Arg}$ & 175.1 & 70.1 & 5 & 47 \\
${ }^{13} \mathrm{C}_{6}{ }^{15} \mathrm{~N}_{4}$ Arg & 185.1 & 75.1 & 5 & 47 \\
Leu & 132.1 & 86.1 & 5.4 & 17 \\
${ }^{13} \mathrm{C}_{6}{ }^{15} \mathrm{~N}$ Leu & 139.1 & 93.1 & 5.4 & 17 \\
CEL-d & 223.2 & 88.1 & 4.7 & 41 \\
RiboLys & 279.0 & 84.0 & 4.5 & 25 \\
Az-RiboLys & 304.0 & 84.0 & 5.5 & 46 \\
\hline
\end{tabular}

\section{Scheme S1. Histone Ribose Glycation}

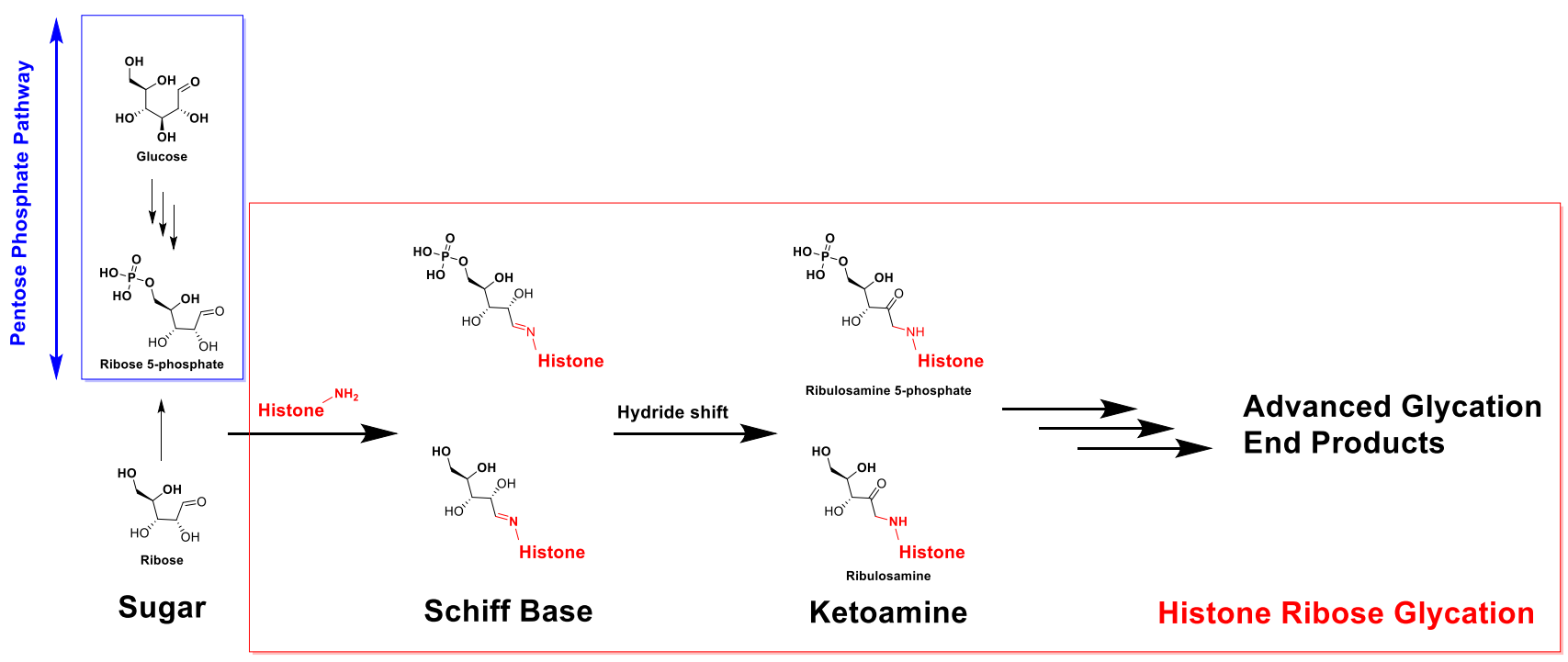




\section{NMR Spectra}

${ }^{1} \mathrm{H}-\mathrm{NMR}$ spectrum of 1 :

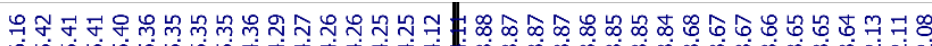

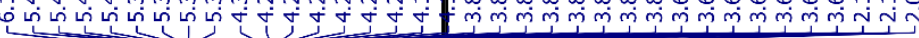<smiles>CC(=O)O[C@@H]1O[C@@H](CO)[C@H](OC(C)=O)[C@H]1OC(C)=O</smiles>

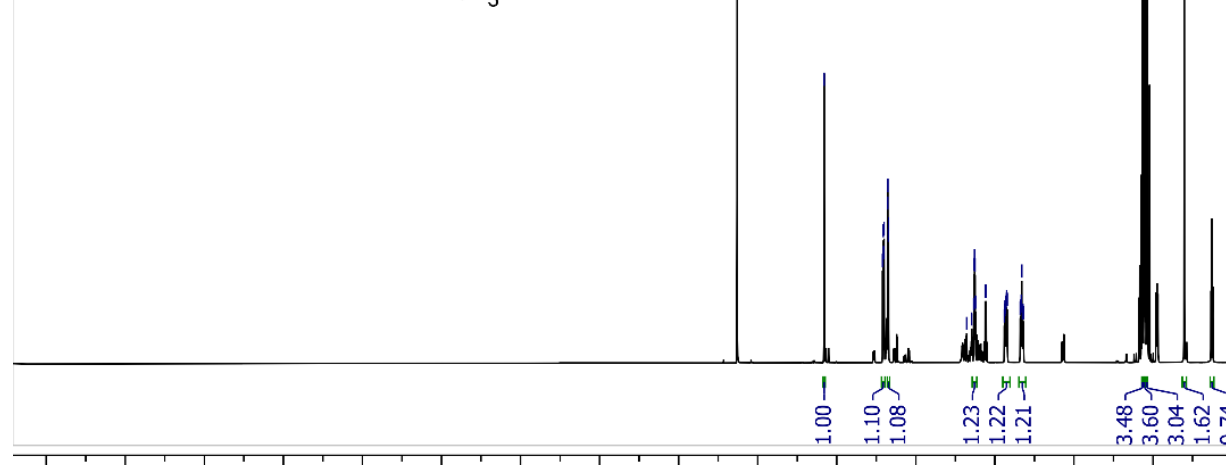

$\begin{array}{lllllllllllllllllllll}16 & 15 & 14 & 13 & 12 & 11 & 10 & 9 & 8 & 7 & 6 & 5 & 4 & 3 & 2 & 1 & 0 & -1 & -2 & -3 & -4 \\ & & & & & \end{array}$

${ }^{13} \mathrm{C}-\mathrm{NMR}$ spectrum of 1 : 
${ }^{1} \mathrm{H}-\mathrm{NMR}$ spectrum of 2 :

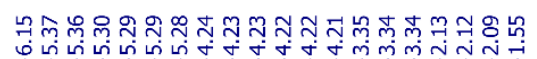

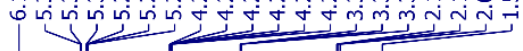<smiles>CC(=O)O[C@@H]1O[C@@H](CI)[C@H](OC(C)=O)[C@H]1OC(C)=O</smiles>

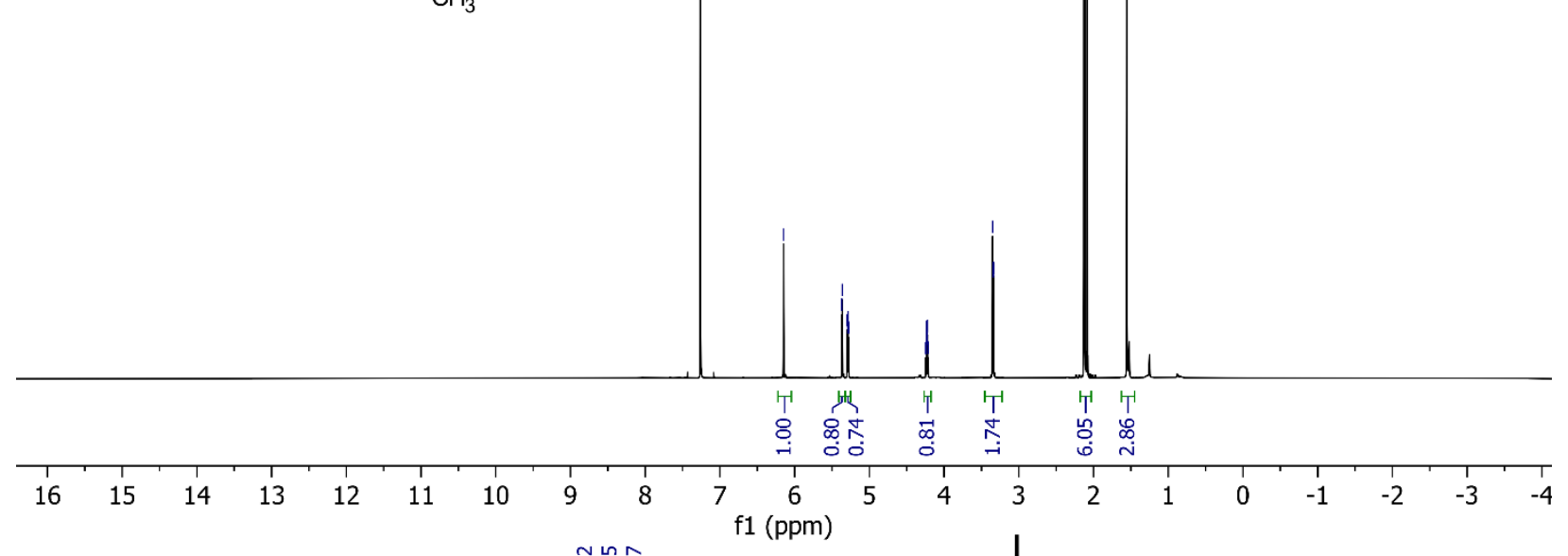

${ }^{13} \mathrm{C}-\mathrm{NMR}$ spectrum of 2 :

ㄴำ

苨

常 $\begin{gathered}m \\ 0 \\ 0\end{gathered}$

ㄴํำ

$\sqrt{4}$

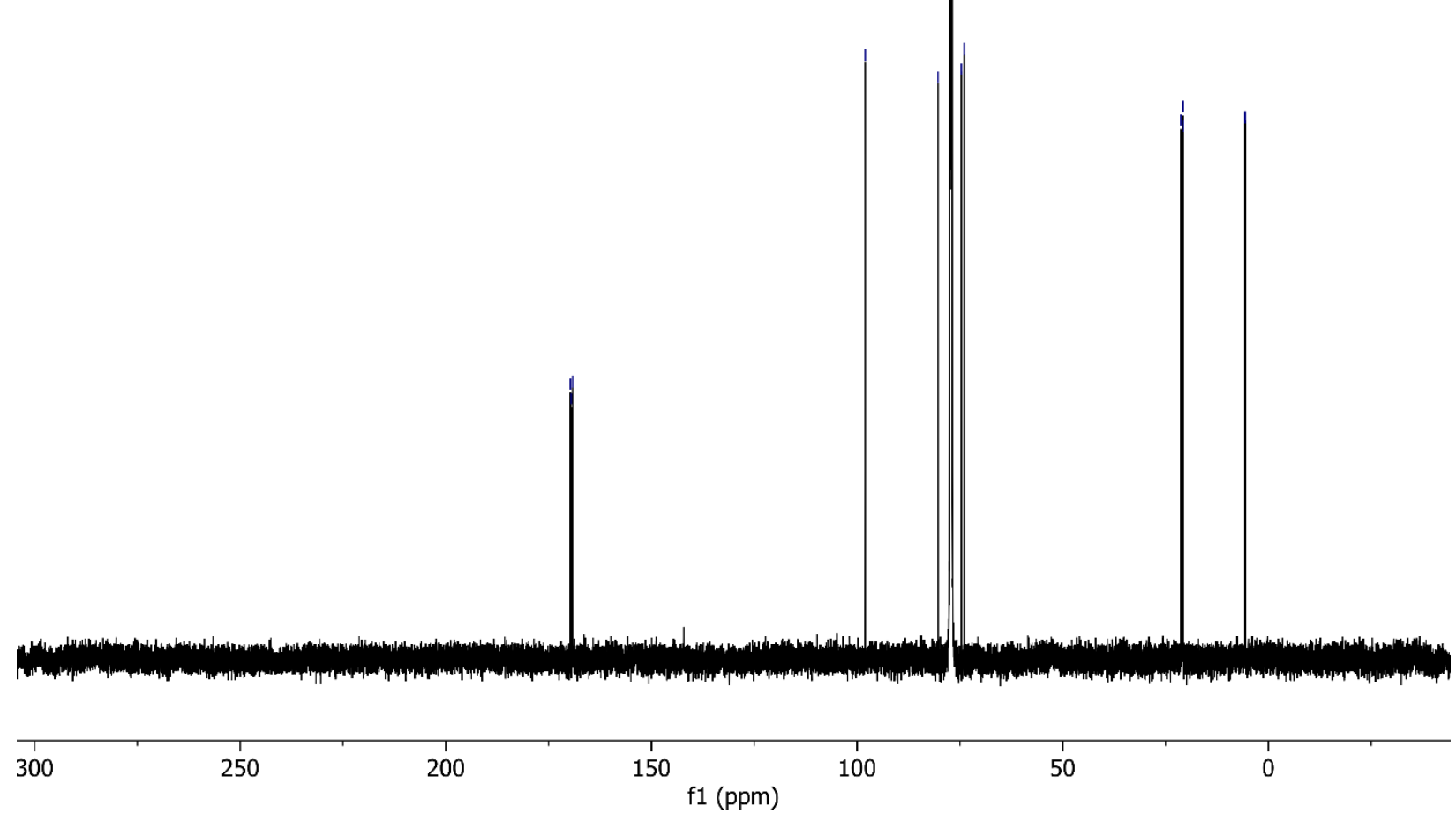


${ }^{1} \mathrm{H}-\mathrm{NMR}$ spectrum of 3 :

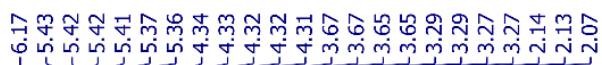

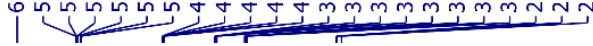

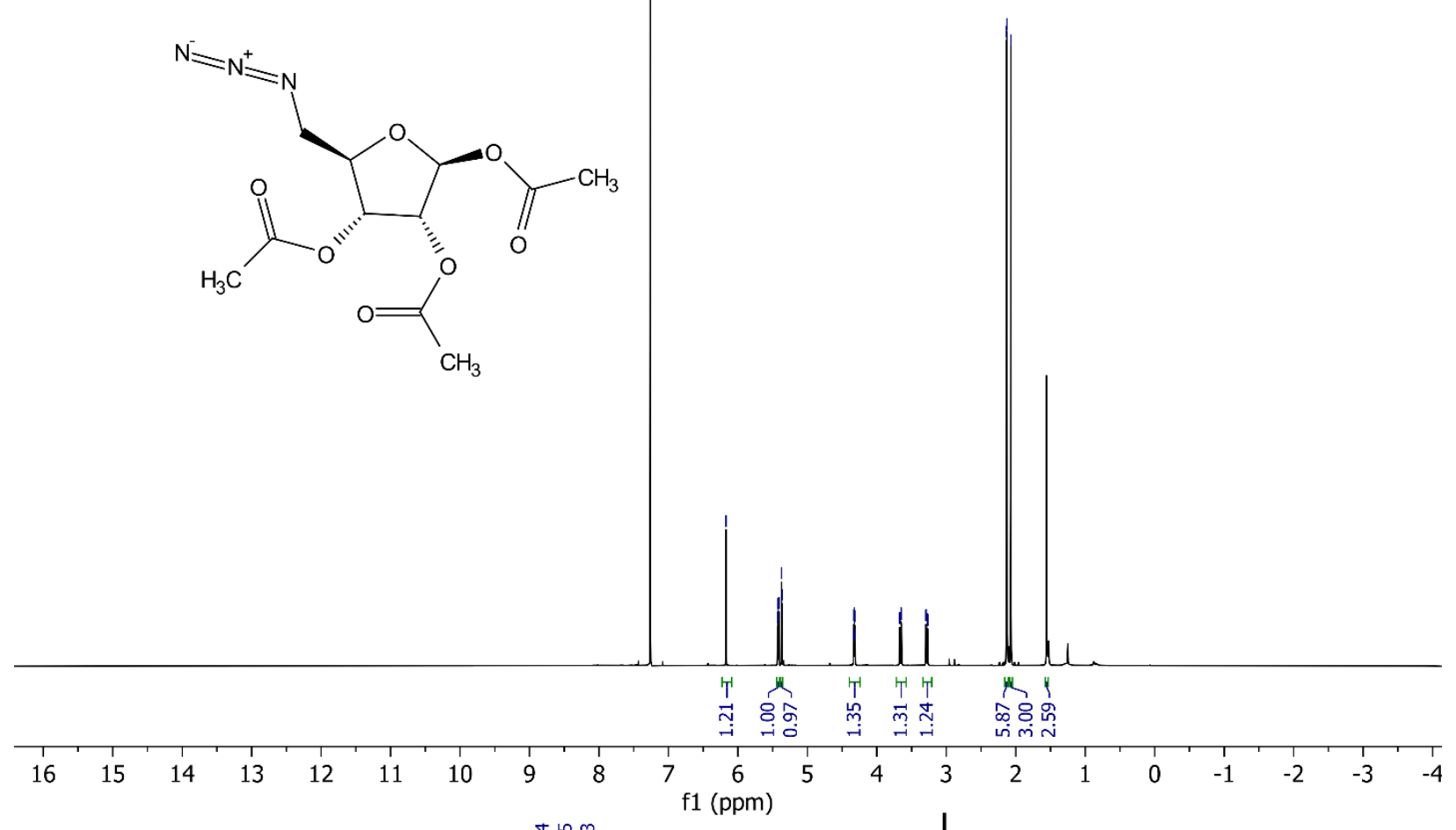

${ }^{13} \mathrm{C}$-NMR spectrum of 3 :

क्ष

兽兽兽

象

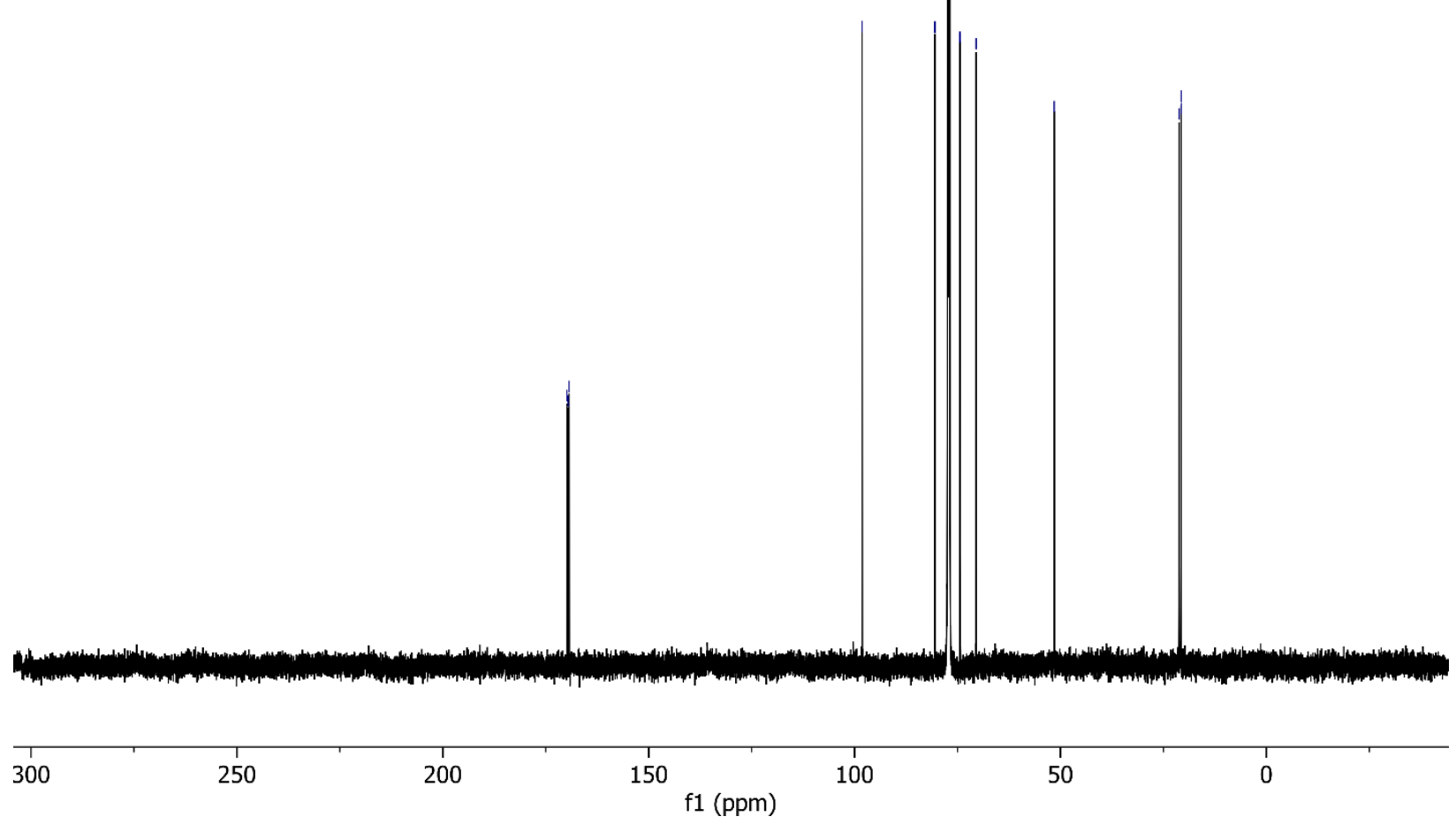


${ }^{1} \mathrm{H}-\mathrm{NMR}$ spectrum of 4 (5-AR):

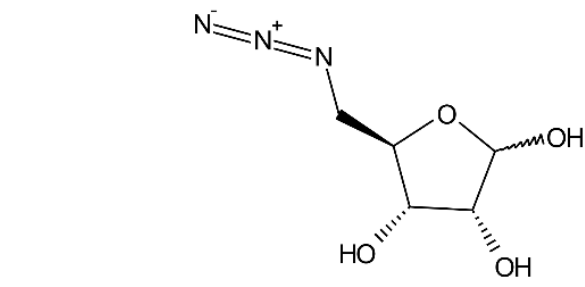

C-NMR spectrum of 4 (5-AR):

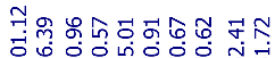

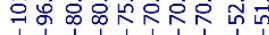

11 पiर V

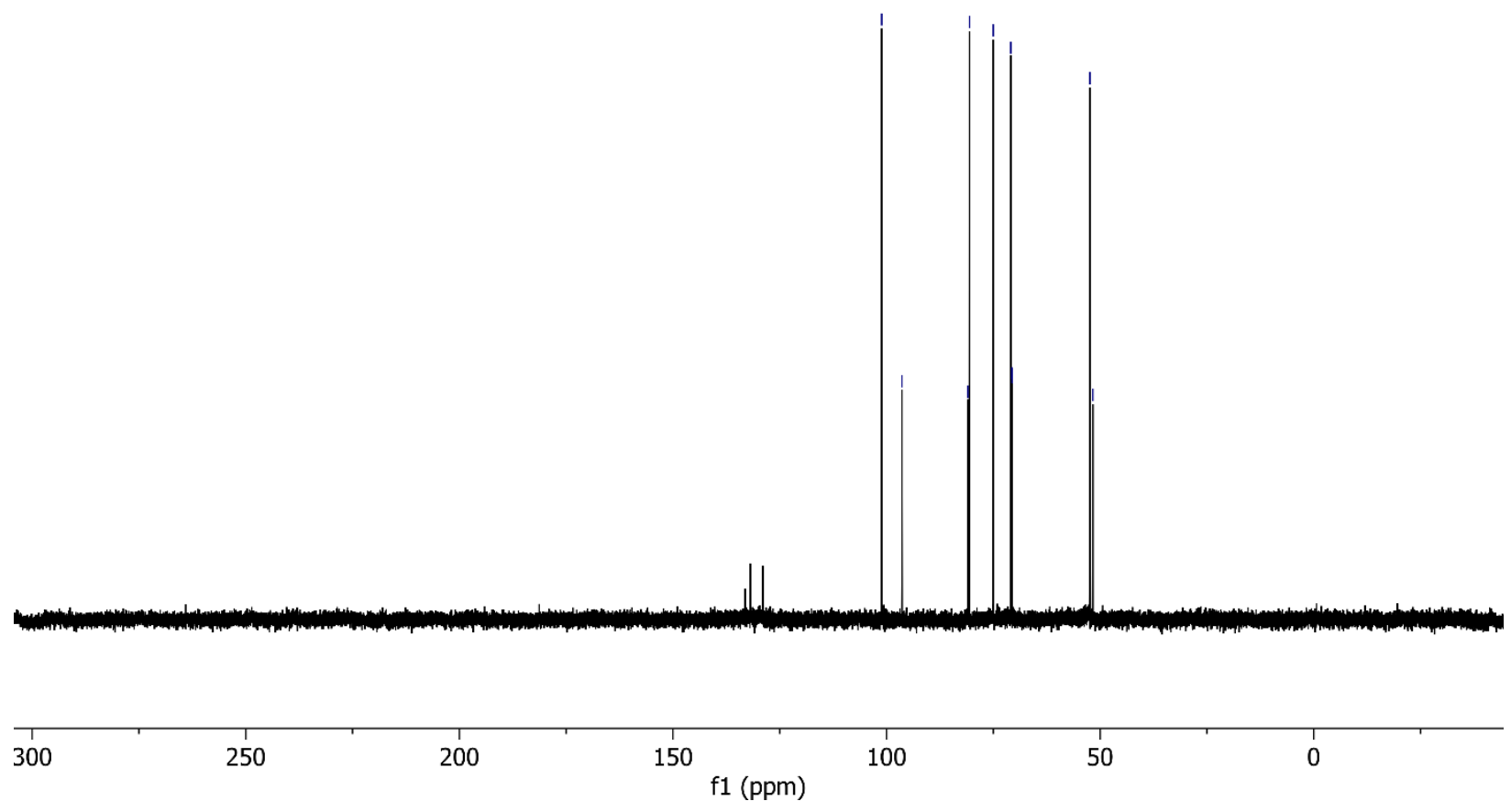


${ }^{1} \mathrm{H}-\mathrm{NMR}$ spectrum of 5 :
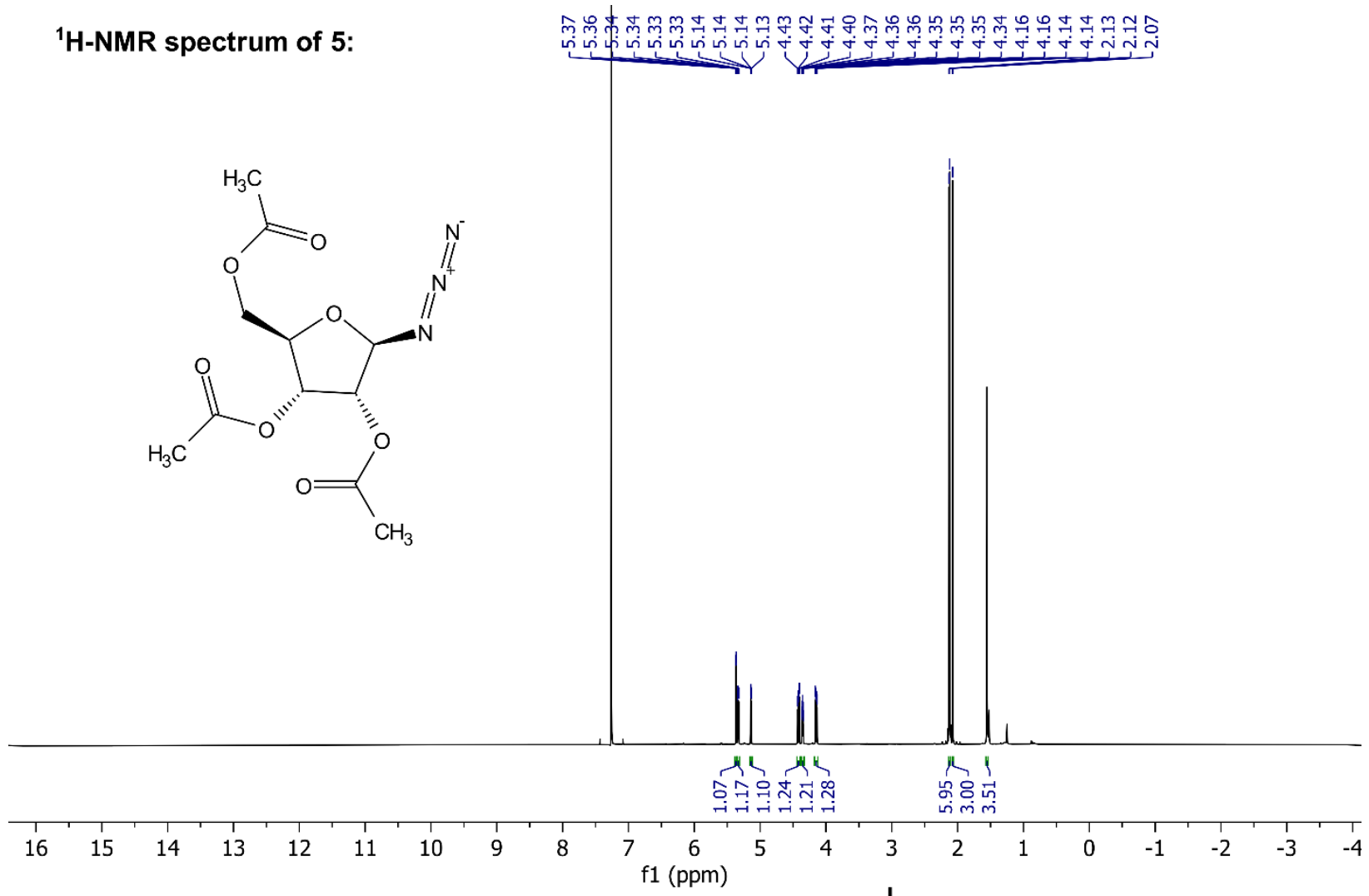

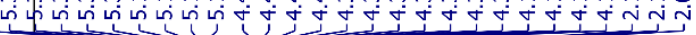

${ }^{13} \mathrm{C}-\mathrm{NMR}$ spectrum of 5 :

№

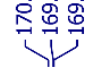

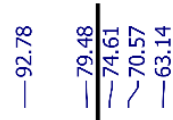

\&: 웅

Y

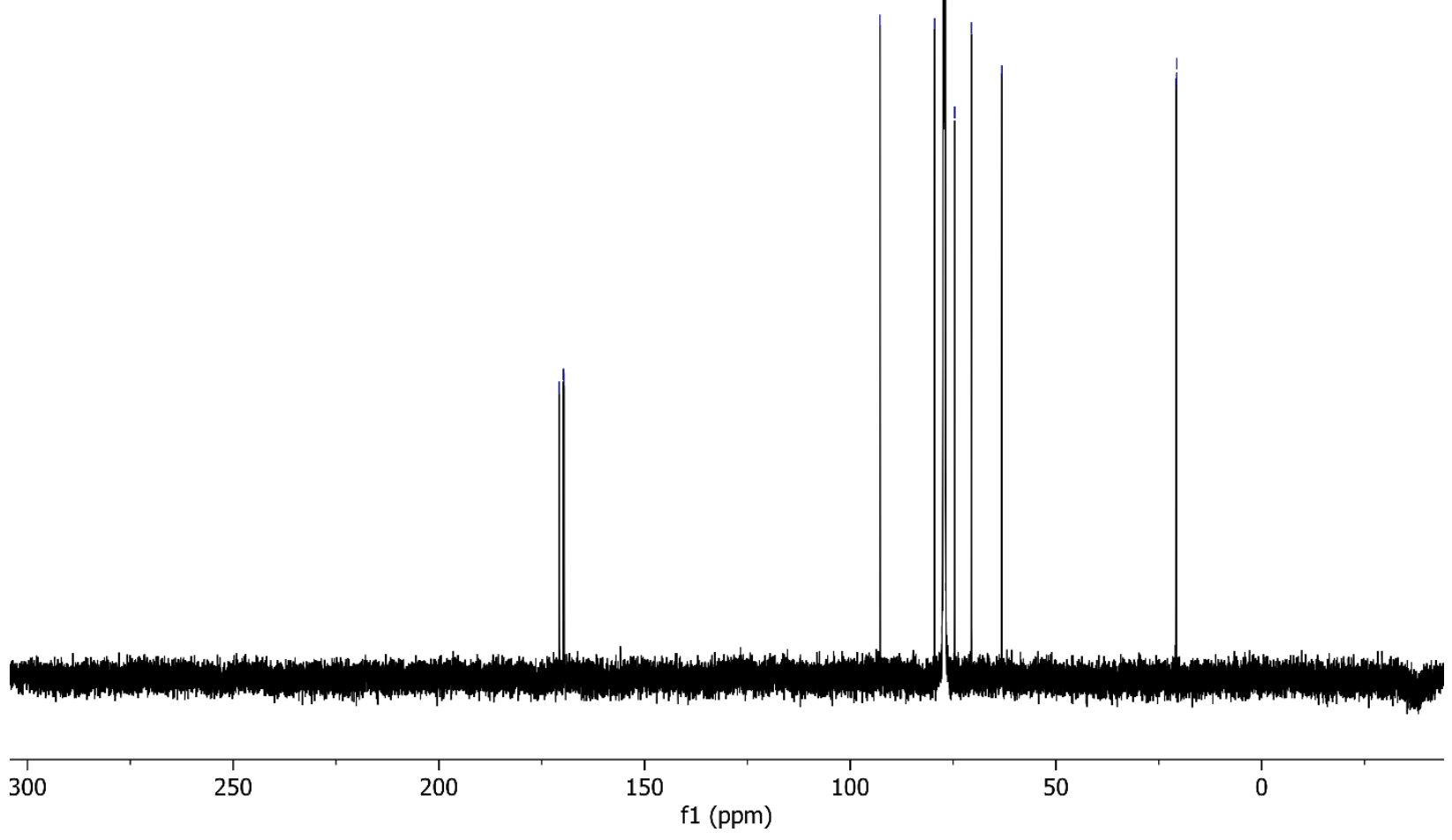


${ }^{1} \mathrm{H}-\mathrm{NMR}$ spectrum of 6 (1-AR):<smiles>[N-]=[N+]=N[C@@H]1O[C@H](CO)[C@@H](O)[C@H]1O</smiles>

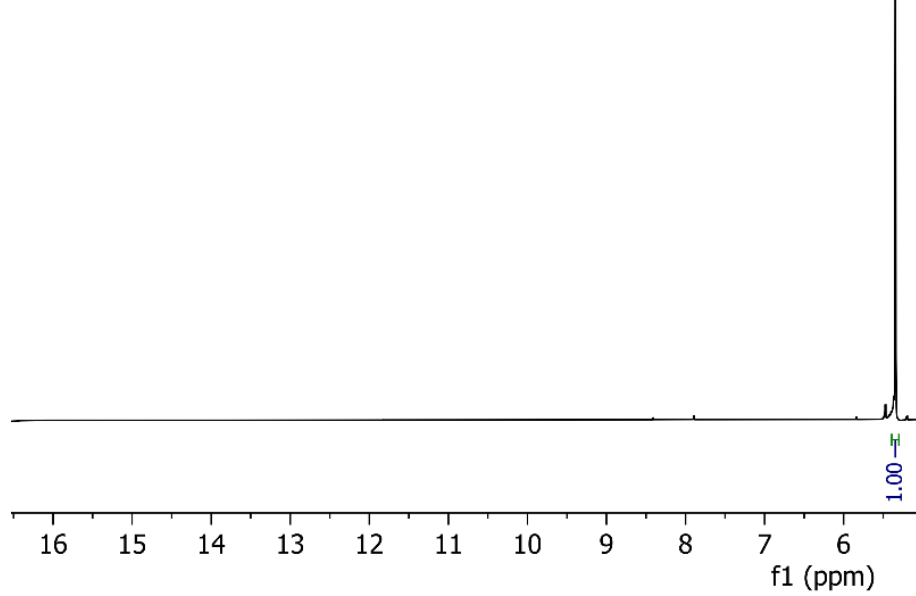

${ }^{13} \mathrm{C}-\mathrm{NMR}$ spectrum of 6 (1-AR):
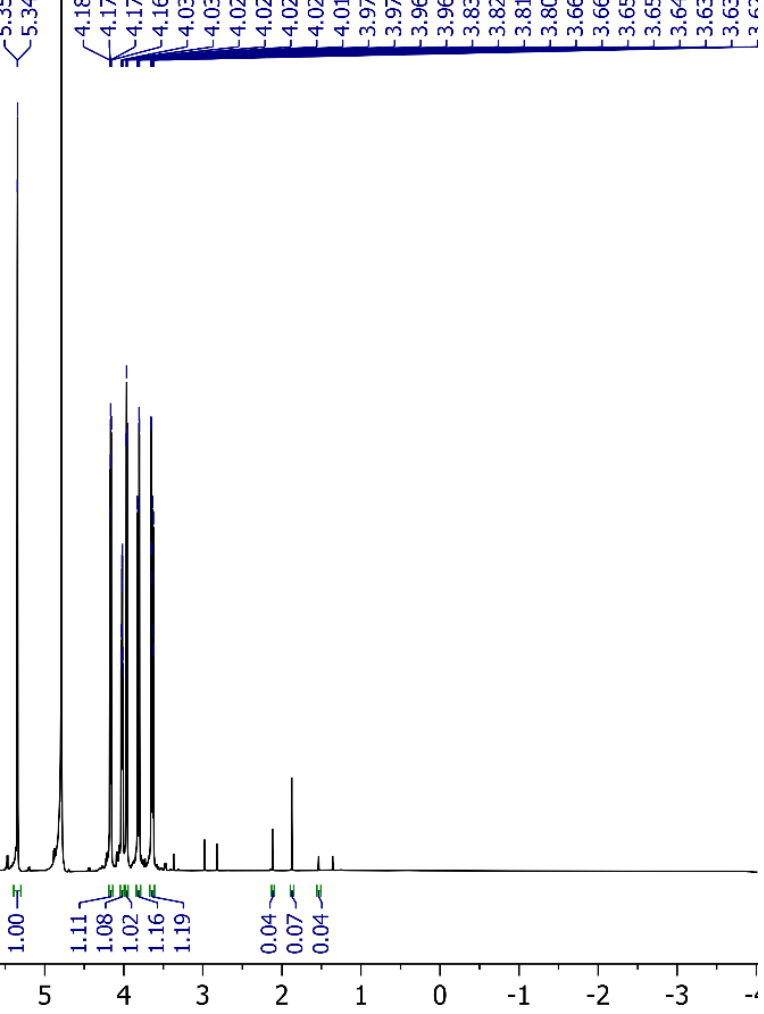

竞

1111

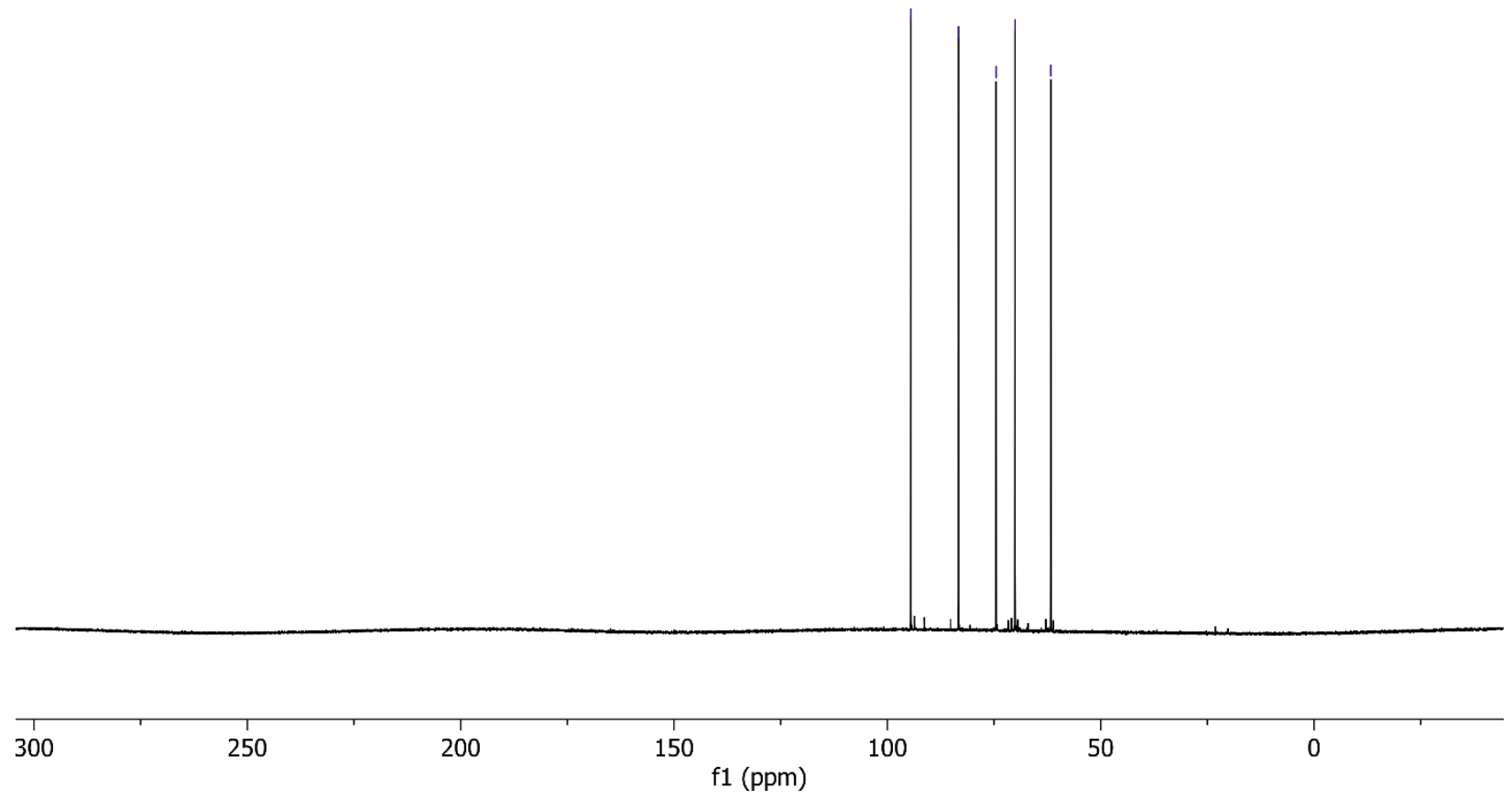




\section{References}

1. Galligan, J. J.; Kingsley, P. J.; Wauchope, O. R.; Mitchener, M. M.; Camarillo, J. M.; Wepy, J. A.; Harris, P. S.; Fritz, K. S.; Marnett, L. J., Quantitative Analysis and Discovery of Lysine and Arginine Modifications. Anal Chem 2017, 89 (2), 1299-1306.

2. Zheng, Q.; Omans, N. D.; Leicher, R.; Osunsade, A.; Agustinus, A. S.; Finkin-Groner, E.; D’Ambrosio, H.; Liu, B.; Chandarlapaty, S.; Liu, S.; David, Y., Reversible histone glycation is associated with disease-related changes in chromatin architecture. Nature Communications 2019, 10 (1), 1289.

3. Zheng, Q.; Maksimovic, I.; Upad, A.; Guber, D.; David, Y., Synthesis of an Alkynyl Methylglyoxal Probe to Investigate Nonenzymatic Histone Glycation. J Org Chem 2020.

4. Maksimovic, I.; Ray, D.; Zheng, Q.; David, Y., Utilizing intein trans-splicing for in vivo generation of sitespecifically modified proteins. Methods Enzymol 2019, 626, 203-222.

5. Shechter, D.; Dormann, H. L.; Allis, C. D.; Hake, S. B., Extraction, purification and analysis of histones. Nat Protoc 2007, 2 (6), 1445-57.

6. $\quad$ Sanghvi, V. R.; Leibold, J.; Mina, M.; Mohan, P.; Berishaj, M.; Li, Z.; Miele, M. M.; Lailler, N.; Zhao, C.; de Stanchina, E.; Viale, A.; Akkari, L.; Lowe, S. W.; Ciriello, G.; Hendrickson, R. C.; Wendel, H. G., The Oncogenic Action of NRF2 Depends on De-glycation by Fructosamine-3-Kinase. Cell 2019, 178 (4), 807-819 e21.

7. Cox, J.; Mann, M., MaxQuant enables high peptide identification rates, individualized p.p.b.-range mass accuracies and proteome-wide protein quantification. Nat Biotechnol 2008, 26 (12), 1367-72.

8. Tyanova, S.; Temu, T.; Sinitcyn, P.; Carlson, A.; Hein, M. Y.; Geiger, T.; Mann, M.; Cox, J., The Perseus computational platform for comprehensive analysis of (prote)omics data. Nat Methods 2016, 13 (9), 731-40.

9. $\quad$ Eden, E.; Navon, R.; Steinfeld, I.; Lipson, D.; Yakhini, Z., GOrilla: a tool for discovery and visualization of enriched GO terms in ranked gene lists. BMC Bioinformatics 2009, 10, 48. 